\title{
THE INFLUENCE OF HIGH AND LOW FAT DIETS AND THYROID SUBSTANCE ON PLASMA LIPIDS OF NEPHROTIC PATIENTS
}

\author{
By IRVINE H. PAGE AND LEE E. FARR \\ (From the Hospital of the Rockefeller Institute for Medical Research, New York)
}

(Received for publication November 30, 1935)

Lactescence of the serum of patients suffering from nephritis with dropsy was observed by Bright and his associate Mr. Bostock (1827 (1)). Christison (1839 (2)) however, probably first recognized that this was fat not unlike that in tissue cells. Epstein (3), in particular, recognized the importance of hypercholesterolemia as a sign in nephrosis.

The later literature concerning nephritic lipemia has been reviewed by Page, Kirk, and Van Slyke (4) who have found that lipemia is the rule, not only in nephrosis, but also in the intermediate chronic stage of hematuric nephritis, and that the different lipid fractions, viz., free and esterified cholesterol, phosphatides, and neutral fats, all tend to increase in similar proportions. In the terminal stage, on the contrary, the lipids were found usually within normal, and sometimes within low normal, ranges, indicating that the lipemic tendency decreases in the final stage of the disease.

In diabetes, statistics have been published (White (5)) indicating that hypercholesterolemia favors the development of arteriosclerosis. Whether nephritic lipemia has a similar influence is unknown, but the possibility makes it appear desirable to ascertain conditions for control of the plasma lipid content in nephritis.

The present paper reports work in which two procedures for this purpose have been tried: (1) Extreme variation of the fat: carbohydrate ratio in the diet and (2) thyroid administration sufficiently intense to cause marked rise in the basal metabolic rate.

Feeding of thyroid substance has also been employed as a therapeutic measure in nephrosis (Dieballa and Illyés (6), Percy $(7,8)$, Epstein (9), and Liu (10)). Epstein recommended it chiefly as a means of correcting the lowered basal metabolism found in these patients. Epstein and Lande (11) believed that it also might aid in reducing the hyperlipemia, since Luden (12) had shown that cholesterol in the blood of patients with myxedema was high, and that feeding thyroid reduced it at a rate parallel to the rise in basal metabolism. They found, too, that cholesterol was low in the blood of patients with hyperthyroidism (confirmed by others (13 to 25$)$ ). There was, therefore, reason to suspect that if thyroid raised the lowered basal metabolism, the hypercholesterolemia might be reduced. For these reasons study of the effect of thyroid on the hyperlipemia of nephrosis and chronic nephritis has seemed to us important.

\section{METHODS OF STUDY}

The patients were studied in the hospital. The four children were confined to bed over the entire period and the three adults over the greater part of it. Diets were prepared in the diet kitchen under the skilful direction of Miss G. Drew. In most cases a diet containing the amount of fat ordinarily consumed by the patient was fed for periods of from one to three months. This diet for the children averaged two to three grams of fat per kilogram of body weight (the weight normal for the height and age). Approximately 30 per cent of the calories were derived from fat. The protein was kept as constant as possible during the experiment. Four grams per kilogram of ideal body weight were fed. This was well taken by the children throughout the period of observation except during acute infections. The carbohydrate in the diet was varied inversely as the fat to maintain a constant caloric intake. Vitamin concentrates were given to all patients in constant amounts throughout.

After a control period with the patient taking the usual diet, diets very low in fat were given for two months. During the next three months they contained as much fat as could be tolerated, with addition of thyroid in the last month. During the final month of the experiment the ordinary diet was resumed. The children tolerated the wide shifts in diet much better than the adults. High 

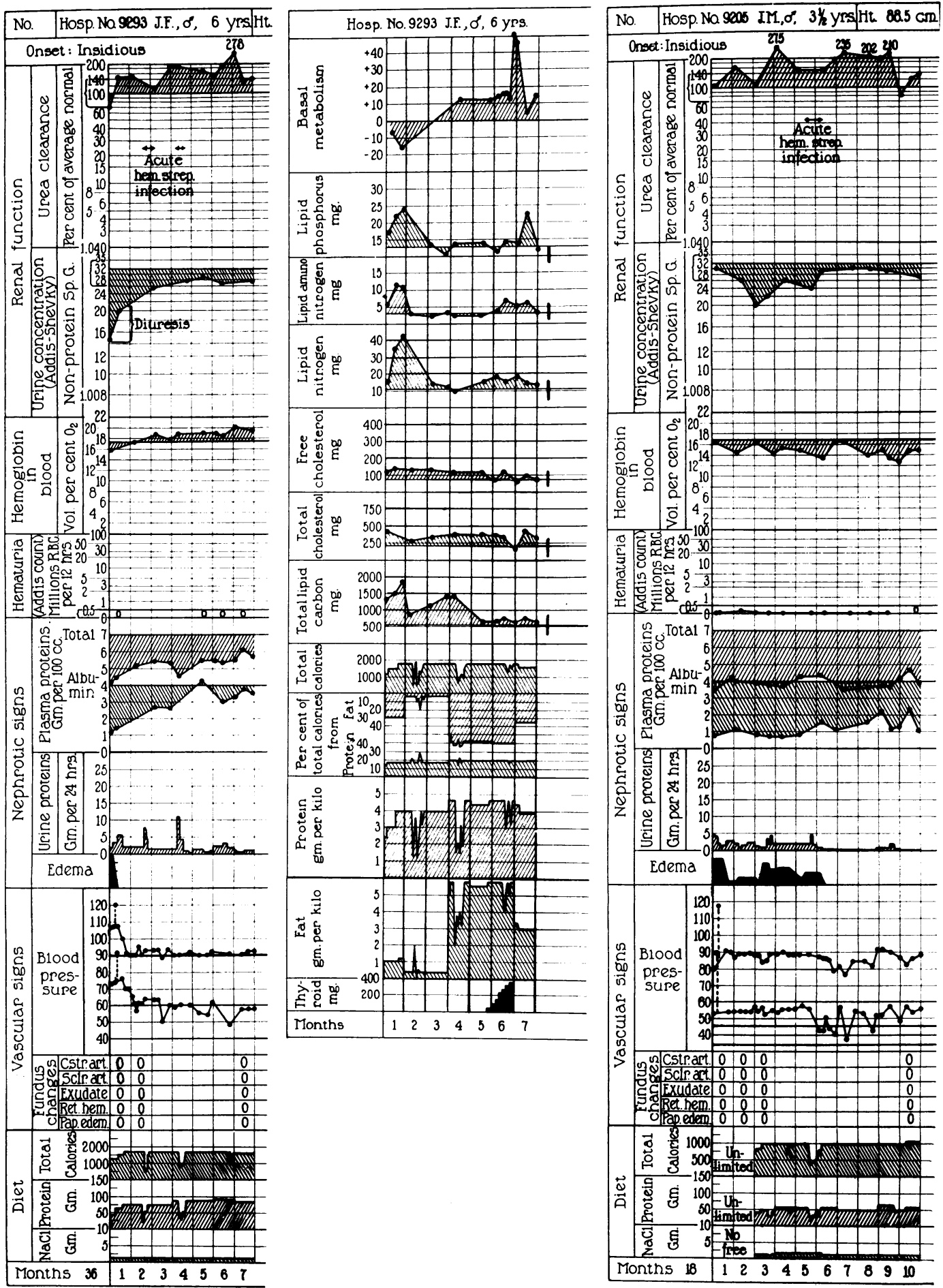

Fig. 1. Cinical Course and Plasma Lipilis in a Child of 6 Years Together with the Clinical Course in a Child of 31/2 Years, Both Cases Suffering from Nephrosis. 

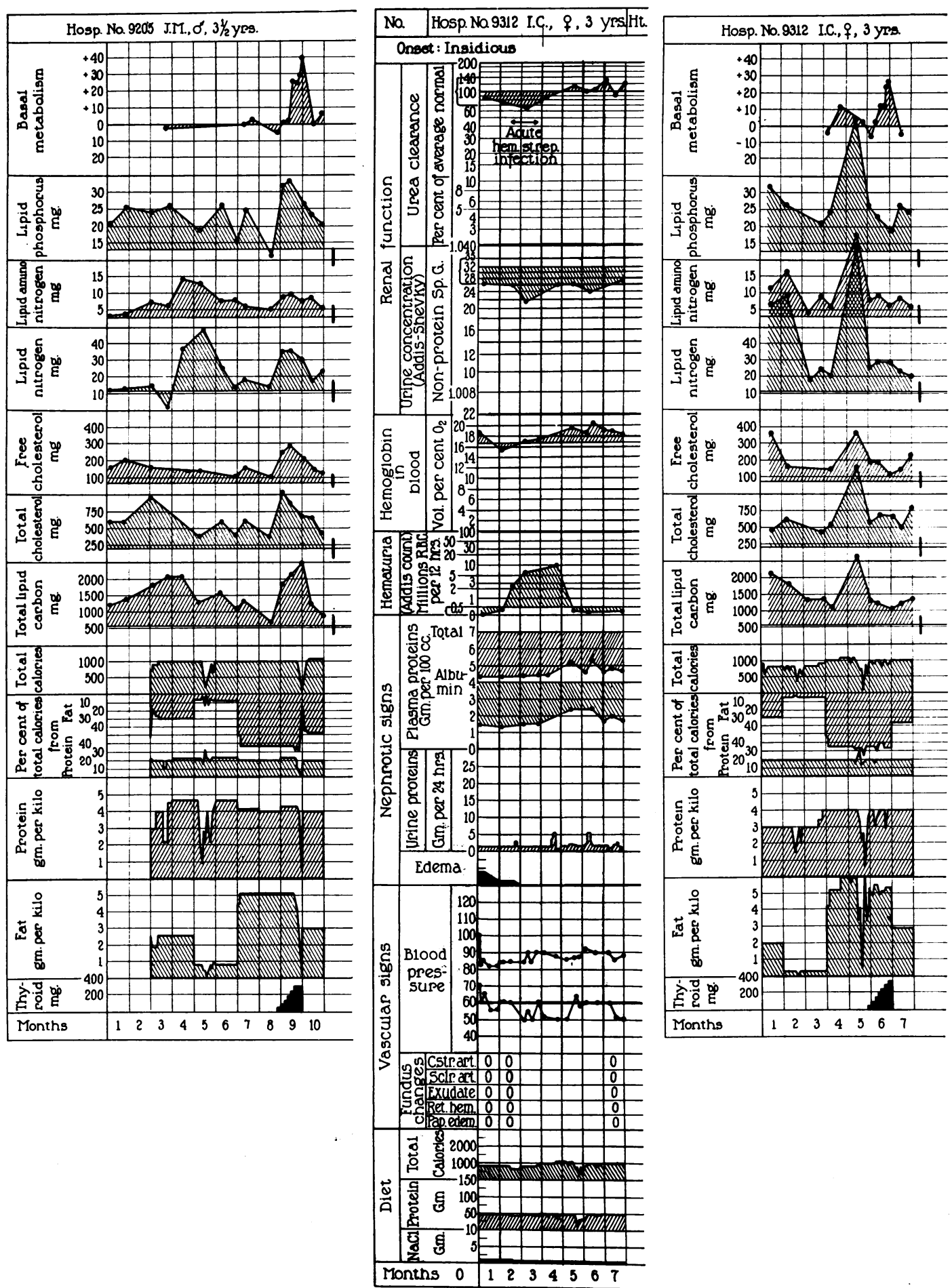

Fig. 2. Plasma lipids in a Child of $3 \frac{1}{2}$ Years Together with the Clinical Course and Plasma Lipids in a Child of 3 Years, Both Cases Suffering from Nephrosis. 
fat diets seemed especially poorly tolerated by the latter.

Blood samples were taken in the morning before breakfast, using heparin as anticoagulant. Plasma lipids were measured by the gasometric method of Kirk, Page, and Van Slyke (26). Duplicate analyses were performed. Renal function was estimated by the urea clearance test of Møller, McIntosh and Van Slyke (27) in the form recently described by Van Slyke, Page, Hiller and Kirk (28) and by the ability to concentrate urine following the technique of Addis and Shevky (29).

\section{EXPLANATION OF CHARTS}

On the charts the mean normal of each value represented is drawn as a base line; the shaded areas between the base line and the points representing observations indicate the degree of deviation above or below the average normal. The brackets at the left of the scales for urea clearance, urine concentration and hematuria, indicate the range of normal variability. The normal base line for hemoglobin varies with the patient's age and sex. Measurements of blood pressure were made daily at 9:30 a.m., but are represented in the charts as average pressures for each week. The black areas representing edema have the following significance: Height of black area in quarters of total space, (1) trace, (2) moderate pitting, (3) marked pitting, (4) general edema with ascites. Morbid changes in the eyegrounds are recorded as follows: (1) Constriction of the arterioles, (2) arteriosclerosis, (3) exudate, (4) hemorrhages, and (5) papilledema. The estimated time elapsing between onset of the disease and admission to the hospital is recorded on the lowest line of the chart, as the first number following the word "months." The other numbers in the bottom row indicate months after first admission.

The charts concerned with the plasma lipids and diets are constructed similarly. The line to which the shading is drawn represents the median values of plasma lipids of normal men as determined by the gasometric method taken from Page, Kirk, Lewis, Thompson and Van Slyke (30). The heavy vertical line at the end of each median base line shows the range of values encountered in normal adults. The normal ranges for children may be slightly different, but do not appear to be greatly so. The figures in the bottom row under the heading "months" correspond to those on the clinical chart of the patient.

\section{CASE REPORTS}

Case reports will be confined chiefly to facts not readily obvious from the charts.
Case 1, Hospital Number 9293 (J. F.) (Figure 1), male, aged 6 years

This patient's chief complaint was edema developing about 2 years before admission to the hospital. This disappeared in about three months, to reappear the next year and remain stubbornly up to the time of admission. When first seen in this hospital he was found to be pale and exceedingly edematous. A high protein (3 grams per $\mathrm{kgm}$. of body weight), high vitamin, low salt diet was immediately started. Shortly after admission a large diuresis occurred during which his weight decreased from 26 to $15.9 \mathrm{kgm}$. The patient remained edema free.

An unusual feature was the markedly elevated urea clearance. Ability to concentrate urine was reduced but rose to nearly normal after two months. The low values during this period probably were due to the fact that diuresis was in progress. Hemoglobin was normal. Plasma proteins were reduced well below the edema level, but rose slowly to well above it (i.e., 5.2 to 5.8 of total plasma protein and 2.2 to 2.7 of albumin (Moore and Van Slyke (31))). The albumin fraction rose from a low level to one which is almost normal. Hematuria was never found. Proteinuria was continuous at a level of about 3 grams in 24 hours. Except for this persistent proteinuria the patient seemed well at the time of discharge. $\mathrm{He}$ was considered to be a case of pure nephrosis.

Case 2, Hospital Number 9205 (J. M.) (Figures 1 and 2), male, 3-1/2 years old

This patient developed edema at the age of 16 months without evidence of antecedent infection. After a few months the edema subsided. It recurred following a severe sunburn, largely disappeared, but again slowly reaccumulated. Admission examination showed that he had marked edema and ascites. Because of diarrhea immediately prior to admission, a low protein, low calorie diet was fed at first. This was rapidly increased as tolerated to a high calorie, high protein diet (4.0 to 4.5 grams per $\mathrm{kgm}$. of ideal body weight). Shortly after admission it was necessary to perform a paracentesis. Subsequently, by giving large quantities of milk containing skimmed milk powder, edema was controlled reasonably well.

Plasma proteins were well below the usual edema level of adults. They showed no tendency to rise although protein excretion in the urine diminished to a trace, and his protein intake was high. $\mathrm{He}$ is one of the rare examples of hypoproteinemia without proteinuria. With salt-free diet and hospital régime edema eventually disappeared, despite the plasma protein deficit. He was considered to be a case of pure nephrosis.

\section{Case 3, Hospital Number 9312 (I. C.) (Figure 2), female, aged 3 years}

This patient's chief complaint was edema developing 3 weeks before admission. Pitting edema and moderate ascites were the only significant physical findings when first seen. She was believed to suffer from nephrosis. 
The urea -clearance was normal on admission, but fell slightly, possibly due to an acute hemolytic streptococcus infection of the throat. The number of red blood cells in the urine was not abnormal except during the period of infection of the throat. Excretion of protein in the urine was fairly constant at one to three grams in 24 hours. Ability to concentrate urine was also slightly reduced. Hemoglobin was normal. Plasma proteins were well below the level at which edema occurs in adults. During the first two months on a high protein, salt-free diet the edema disappeared, although the level of plasma proteins rose but slightly. Except for disappearance of edema and the return of the urea clearance to normal there was little change in the patient's clinical condition throughout the experiment.

\section{Case 4, Hospital Number 9259 (T. M.) (Figure 3), female, aged 2-1/2 years}

This patient's chief complaint was increasing edema developing one month before admission. Examination showed that the child was acutely ill with extreme edema and ascites. She did not respond to treatment quickly, and during the first two months it was necessary to perform two paracenteses. Progress toward recovery was frequently punctuated by infections. Edema and ascites were extreme during the first three months, disappeared only to reappear for two months and again disappear. Despite the nearly normal urea clearance, the loss of ability to concentrate urine, slight anemia, occasional slight hematuria and transient rises in blood pressure above normal indicated that she was suffering from hemorrhagic nephritis in the nephrotic stage.

\section{Case 5, Hospital Number 8936 (H. B.) (Figures 3 and 4), female, aged 37 years}

This patient complained of gradually increasing edema for six months before admission to this hospital. Physical examination showed moderate ascites. The eyegrounds were normal, but the blood pressure was slightly elevated.

Urea clearance, which was 52 per cent of normal on admission, gradually fell to 11 per cent of normal. Ascites was constantly present. Blood pressure gradually rose to an average level of $170 / 100 \mathrm{~mm}$. $\mathrm{Hg}$. She was considered a case of hemorrhagic nephritis in the nephrotic stage.

Case 6, Hospital Number 7049 (A. C.) (Figure 4), male, aged 23 years

This patient became ill two weeks prior to admission (now 5 years ago). Generalized edema was the most marked symptom. Since that time he has exhibited signs and symptoms which at one time suggested nephrosis, and at another hemorrhagic nephritis. Urea clearance has been normal much of the time, but fell to 6 per cent of normal after administration of gum acacia to relieve edema. Ability to concentrate urine has remained consistently reduced. Hemoglobin has also va- ried from normal values to about one-half of normal. For periods of many months the number of red blood cells excreted in the urine was normal, but at times rose to as high as $5,000,000$ in 12 hours. Plasma proteins have usually been at or below the edema level. Excretion of protein in the urine varied greatly, but usually was large. Edema was usually present, at times being severe, occasionally disappearing entirely. Blood pressure was normal or slightly elevated. No morbid changes were observed in the eyegrounds. Except for ascites, the physical examination was not remarkable.

Through the experimental period he took a high protein diet. Reduction of fat was well tolerated, but attempts to feed him high amounts of fat were unsuccessful. He appeared to tolerate fat poorly. It was also impossible to administer large doses of thyroid, as he complained bitterly of ringing in the ears, faintness and excessive perspiration.

\section{Case 7, Hospital Number 8740 (G. P.) (Figure 5), female, aged 19 years}

Eighteen months before admission she noticed gradually increasing swelling of her ankles. Protein and red blood cells were found in her urine. After a short period of rest in bed she resumed her work. Edema reappeared and during the next eighteen months was almost constantly present. Examination showed that she was very pale and appeared chronically ill. Her face and legs were swollen with edema. Fluid was present in her chest and abdomen. Eyegrounds were normal. The blood pressure was $130 / 90 \mathrm{~mm}$. $\mathrm{Hg}$.

The urea clearance was 103 per cent of normal on admission, but gradually fell. Ability to concentrate urine was also impaired. Moderate anemia was present. Hematuria was above normal but gradually subsided. Plasma proteins were initially well below the level at which edema appears, and excretion of protein in the urine was large. Blood pressure, although initially but slightly elevated above normal, gradually rose to an average height of $170 / 104 \mathrm{~mm}$. Hg. Bilateral renal denervation was performed. The results of this operation were reported elsewhere by Page and Heuer (32).

During the first twelve months in the hospital she was given a high protein diet. The fat in it averaged about 1.3 grams per $\mathrm{kgm}$. of body weight, or enough to furnish about 35 per cent of the total calories, but this may be considered only a rough figure. During this period there was some reduction in renal efficiency and marked reduction in edema. Hyperlipemia gradually subsided, but not to a normal level. Thyroid was then administered in large doses.

\section{DISCUSSION}

Plasma lipids were studied of three children (Cases 1, 2, 3) suffering from pure nephrosis, and of one child (Case 4) and three adults (Cases $5,6,7)$ with hemorrhagic nephritis in the nephrotic stage. During the first month or two, 

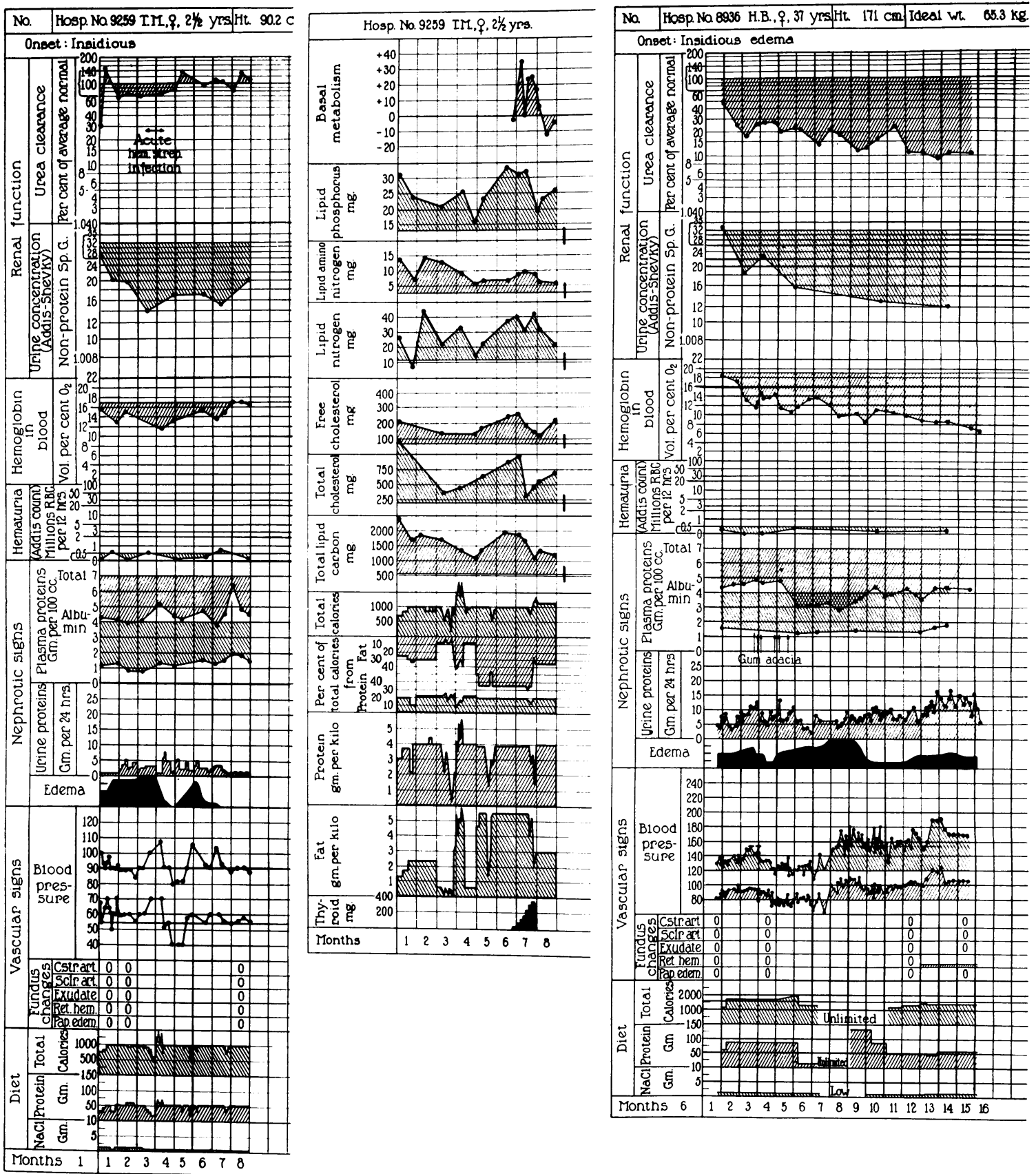

Fig. 3. Cilinical Course and Plasma lipids in a Child of 21/2 Years Together with the Cinical Course in a Patiext of 37 Years, Both Cases Suffering from Hemorrhagic Nephritis in thf Nephrotic Stage.

which was employed as a control period, clinical improvement in the children was marked, especially as regards loss of ascites and edema, while during the ensuing months it was less evident. The adults had been in the hospital for some months and their condition changed but slowly. We have been unable to find changes in signs or symptoms in the patients which were regularly associated with alteration in any of the plasma lipid fractions (compare clinical charts with those 

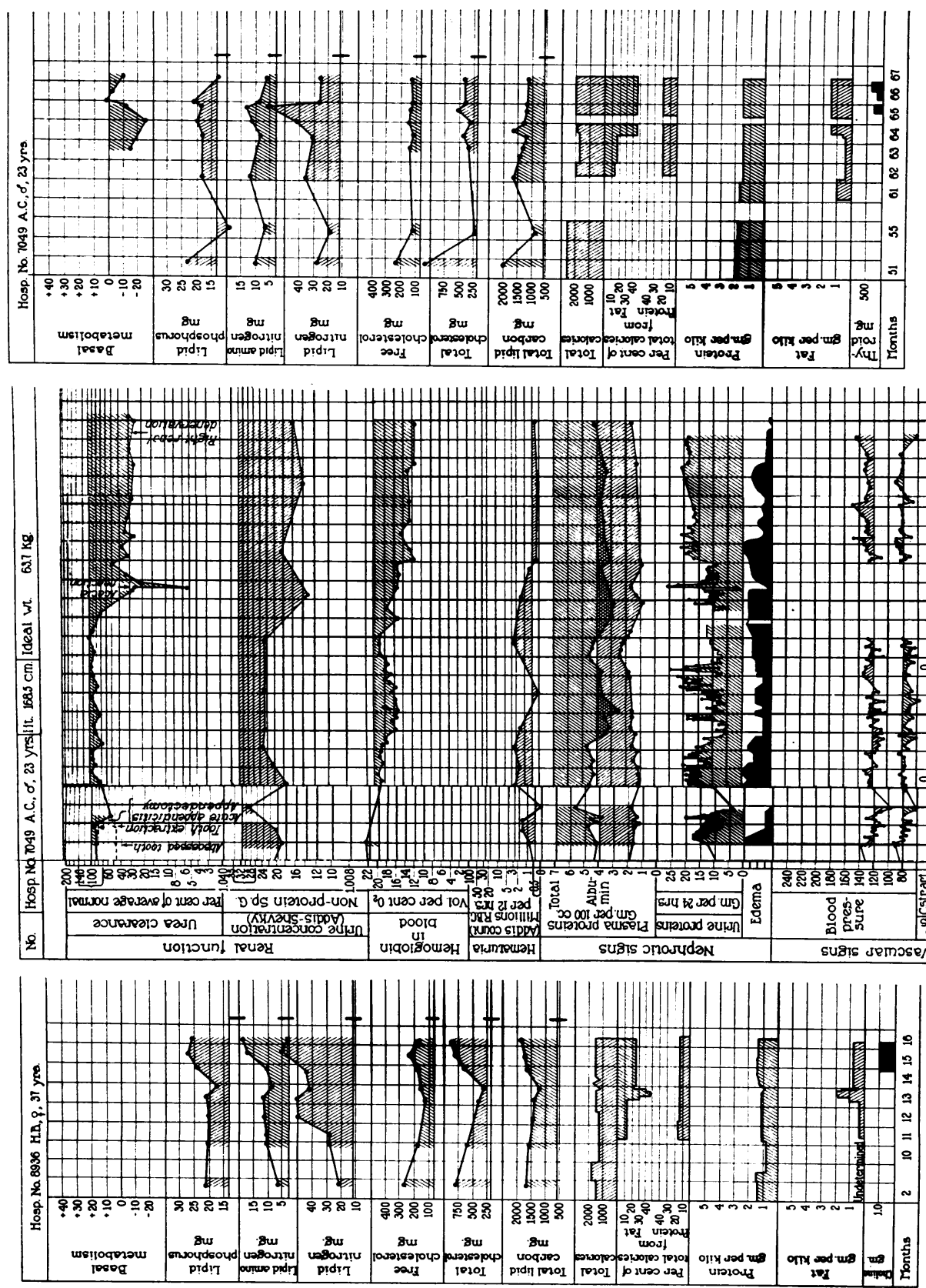

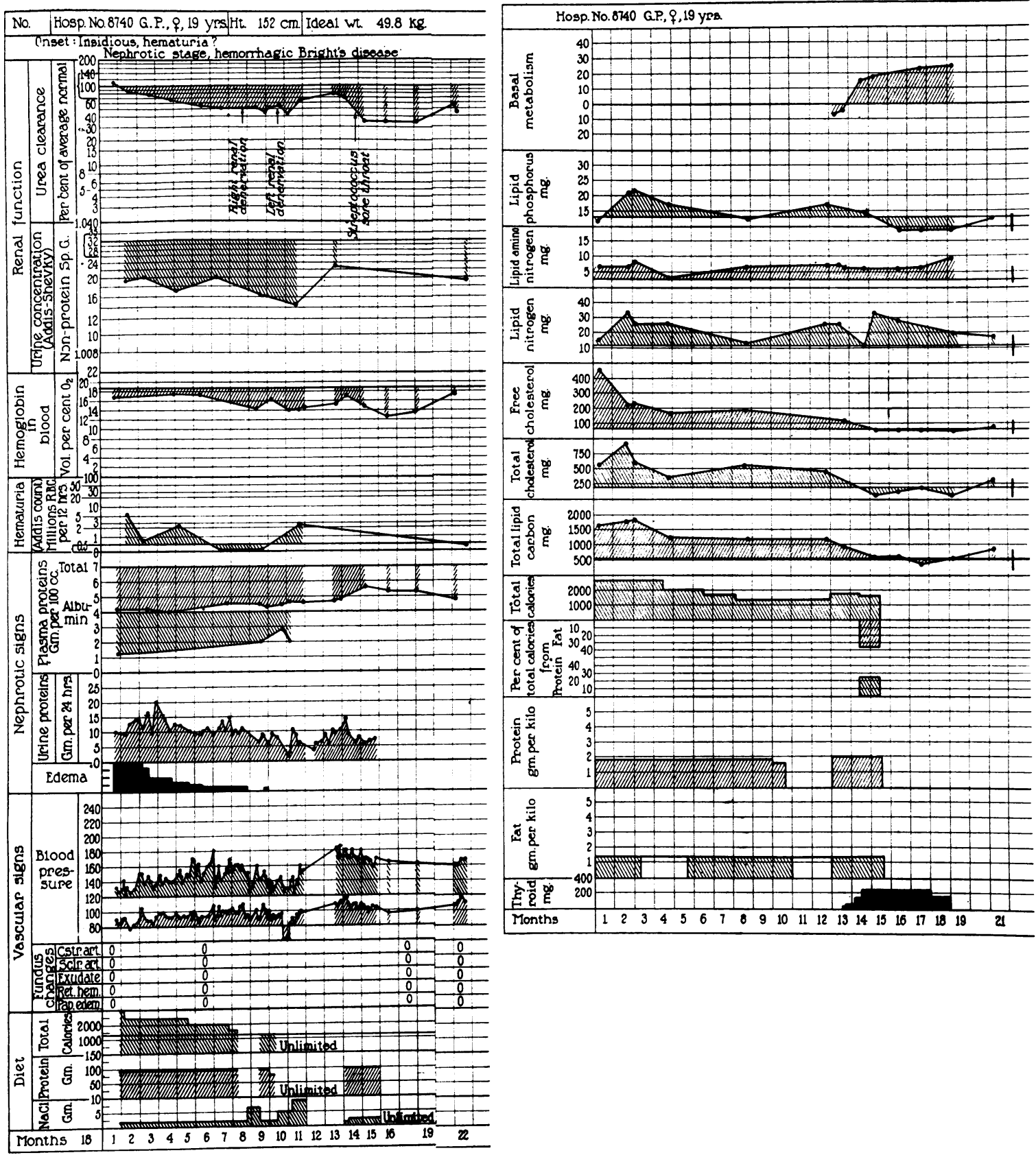

Fig. 5. Clinical Course and Plasma Lipids of a Case of Hemorrhagic Nephritis in the Nephrotic Stage in a Patient of 19 Years.

showing plasma lipid values). For ease of comparison changes in plasma lipids have been summarized (Table I).

These data (Table I) show that plasma lipids during the postabsorptive state in patients suffering from nephrosis or the nephrotic stage of hemorrhagic nephritis with hyperlipemia are not regularly influenced by the amount of fat in the diet or by administration of thyroid. The results suggest that the removal of lipids from the blood to tissue depôts is controlled by unknown factors, other than the fat intake. Otherwise, it might be 
PLASMA LIPIDS IN NEPHROSIS

TABLE I

Summary of the effect of variation in dietary fat and administration of thyroid on the plasma lipids in patients*

\begin{tabular}{|c|c|c|c|c|c|c|c|c|c|c|}
\hline \multirow{3}{*}{$\begin{array}{l}\text { Case } \\
\text { num- } \\
\text { ber }\end{array}$} & \multirow{3}{*}{ Age } & \multirow{3}{*}{ Disease } & \multirow{3}{*}{$\begin{array}{l}\text { Diet, } \\
\text { per cent of total } \\
\text { calories supplied by fat }\end{array}$} & \multicolumn{6}{|c|}{ Changes in plasma lipids } & \multirow{3}{*}{$\begin{array}{c}\text { Basal } \\
\text { metab- } \\
\text { olism }\end{array}$} \\
\hline & & & & \multirow{2}{*}{$\begin{array}{l}\text { Total } \\
\text { lipid } \\
\text { carbon }\end{array}$} & \multicolumn{2}{|c|}{ Cholesterol } & \multirow{2}{*}{$\begin{array}{l}\text { Total } \\
\text { lipid } \\
\text { nitrogen }\end{array}$} & \multirow{2}{*}{$\begin{array}{c}\text { Lipid } \\
\text { amino } \\
\text { nitrogen }\end{array}$} & \multirow{2}{*}{$\begin{array}{l}\text { Lipid } \\
\text { phos- } \\
\text { phorus }\end{array}$} & \\
\hline & & & & & Total & Free & & & & \\
\hline 1 & $\begin{array}{c}\text { years } \\
6\end{array}$ & Nephrosis & $\begin{array}{l}30 \\
5 \\
60 \\
60+\text { Thyroid } \\
35\end{array}$ & $\frac{+}{\overline{0}}$ & $\begin{array}{l}0 \\
0 \\
0 \\
0 \\
0\end{array}$ & $\begin{array}{l}\mathbf{0} \\
\mathbf{0} \\
\mathbf{0} \\
\mathbf{0} \\
\mathbf{0}\end{array}$ & $\begin{array}{c}+\frac{+}{-}- \\
0 \\
0 \\
0\end{array}$ & $\begin{array}{c}++ \\
-\frac{1}{0} \\
0 \\
0\end{array}$ & $\begin{array}{l}+ \\
0 \\
0 \\
+\end{array}$ & $\begin{array}{c}\text { per cent } \\
-16 \\
+11 \\
+51 \\
+6\end{array}$ \\
\hline 2 & $3 \frac{1}{2}$ & Nephrosis & $\begin{array}{l}\text { Unlimited } \\
30 \\
8 \\
62 \\
50+\text { Thyroid }\end{array}$ & $\begin{array}{c}t \\
+ \\
-- \\
+++\end{array}$ & $\begin{array}{l}+t \\
-- \\
\pm \\
+t\end{array}$ & $\begin{array}{c}0 \\
0 \\
0 \\
0 \\
++\end{array}$ & $\begin{array}{c}0 \\
+++t \\
-\frac{0}{0} \\
++\end{array}$ & $\begin{array}{c}+ \\
++ \\
-\frac{1}{0} \\
+\end{array}$ & $\begin{array}{c}0 \\
0 \\
\frac{+}{+}+ \\
+\frac{+}{+}+\end{array}$ & $\begin{array}{l}-2 \\
+40\end{array}$ \\
\hline 3 & 3 & Nephrosis & $\begin{array}{l}7 \\
64 \\
64+\text { Thyroid } \\
38\end{array}$ & $\begin{array}{c}-- \\
0 \\
0 \\
0\end{array}$ & $\begin{array}{l}\mathbf{0} \\
0 \\
0 \\
0\end{array}$ & $\begin{array}{c}-\frac{-}{0} \\
\frac{1}{+}\end{array}$ & $\begin{array}{c}---- \\
0 \\
0 \\
0\end{array}$ & $\begin{array}{c}---- \\
0 \\
0 \\
0\end{array}$ & $\begin{array}{c}-\frac{0}{0} \\
\frac{1}{+}\end{array}$ & $\begin{array}{r}-3 \\
+26 \\
-6\end{array}$ \\
\hline 4 & $2 \frac{1}{2}$ & $\begin{array}{l}\text { Hemorrhagic } \\
\text { nephritis in } \\
\text { nephrotic } \\
\text { stage }\end{array}$ & $\begin{array}{l}30 \\
8 \\
64 \\
64+\text { Thyroid } \\
35\end{array}$ & $\frac{-}{+\frac{1}{0}}$ & $\frac{t}{t+t} \frac{t}{t}$ & $\begin{array}{c}\overline{0} \\
++ \\
\frac{+}{+}\end{array}$ & $\begin{array}{c}-+t \\
+\frac{1}{0}+ \\
-\end{array}$ & $\begin{array}{c}-+ \\
-\frac{1}{0}- \\
0 \\
-\end{array}$ & $\begin{array}{c}\overline{-} \\
+\overline{+}+ \\
-\frac{-}{+}\end{array}$ & $\begin{array}{r}3 \\
+36 \\
-11\end{array}$ \\
\hline 5 & 37 & $\begin{array}{l}\text { Hemorrhagic } \\
\text { nephritis in } \\
\text { nephrotic } \\
\text { stage }\end{array}$ & $\begin{array}{l}12 \\
25 \\
\text { Choline }\end{array}$ & $\begin{array}{l}0 \\
0 \\
+\end{array}$ & $\begin{array}{l}- \\
++ \\
++\end{array}$ & $\begin{array}{l}\dot{t} \\
+\end{array}$ & $\begin{array}{c}t+t \\
t+\end{array}$ & $\begin{array}{c}0 \\
0 \\
++\end{array}$ & $\begin{array}{c}0 \\
++\end{array}$ & \\
\hline 6 & 23 & $\begin{array}{l}\text { Hemorrhagic } \\
\text { nephritis in } \\
\text { nephrotic } \\
\text { stage }\end{array}$ & $\begin{array}{l}\text { Unlimited } \\
18 \\
48 \\
48+\text { Thyroid }\end{array}$ & $\begin{array}{c}-\frac{-}{0}+ \\
0 \\
0\end{array}$ & $\begin{array}{c}---- \\
0 \\
0 \\
0\end{array}$ & $\begin{array}{c}-- \\
0 \\
0 \\
0\end{array}$ & $\begin{array}{c}-+ \\
0 \\
+ \\
++-\end{array}$ & $\begin{array}{c}-+ \\
0 \\
0 \\
0\end{array}$ & $\begin{array}{c}-\frac{-}{0}+ \\
0 \\
0\end{array}$ & $\begin{array}{l}-24 \\
+\quad 1\end{array}$ \\
\hline 7 & 20 & $\begin{array}{l}\text { Hemorrhagic } \\
\text { nephritis in } \\
\text { nephrotic } \\
\text { stage }\end{array}$ & $\begin{array}{l}\text { Unlimited } \\
\text { Unlimited +Thyroid } \\
\text { Unlimited }\end{array}$ & $\frac{--}{+}$ & $\begin{array}{c}--- \\
-\frac{-}{+}\end{array}$ & $\frac{----}{0}$ & $\frac{+--t}{\frac{-}{0}}$ & $\begin{array}{l}0 \\
0 \\
0\end{array}$ & $\begin{array}{c}++-+ \\
\frac{-}{+}\end{array}$ & $\begin{array}{r}-8 \\
+23\end{array}$ \\
\hline
\end{tabular}

* Changes in plasma lipids are indicated in the table as + or.-++++ indicates very marked rise. indicates very marked fall.

expected that absorption of large amounts of fat over long periods of time would increase the hyperlipemia, and conversely fat restriction would decrease it.

The only petroleum-ether soluble plasma constituents which were at all consistently influenced by dietary fat were the total lipid nitrogen and lipid amino nitrogen. As indicated by Van Slyke, Page, Kirk, and Farr (33) it appears probable that the greater part of the nitrogen belongs to bases which are not lipids in the sense that they are in fatty acid or sterol compounds. In the children, who were by far the most satisfactory subjects because of their ability to consume and digest the low or high fat diets with ease, reduction in fat in the diet was associated with marked fall in both fractions. Although lipid amino nitrogen values often varied independently of total lipid nitrogen, usually they fell along with the latter when dietary fat was reduced. This reduced level was maintained by the lipid amino nitrogen and usually by the total lipid nitrogen when fat was again increased in the diet. Changes in lipid phosphorus were not marked in most cases, slight reduction occurring on lowering fat intake, without corresponding rise on increasing it. Cholesterol, both 
free and total, changed irregularly. Total lipid was reduced in most cases on low fat diets, but increase in the fat was associated either with continued reduction or rise.

The effect of thyroid on the plasma lipids was unpredictable, sometimes a rise occurring and sometimes a fall. No relationship between metabolic rate and plasma lipid was apparent. Although thyroid had no general demonstrable effect on plasma lipids of the children, in one adult who received it lipids fell to normal and remained there. Whether this sequence was due to the thyroid administration is uncertain.

Choline administration in one case (Number 5) was associated with rise in all lipids but phosphatides. It is impossible to be certain that this rise was caused by the choline and would not have occurred spontaneously.

\section{CONCLUSIONS}

Plasma lipids (total lipids, cholesterol, cholesterol esters, lipid phosphorus), during the postabsorptive state in patients suffering from nephrosis or the nephrotic stage of hemorrhagic nephritis with hyperlipemia, are not regularly influenced by the amount of fat in the diet or by administration of thyroid. Lipid amino nitrogen and total lipid nitrogen usually fall when fat in the diet is reduced. Feeding of fat to such patients is not contraindicated by its effect on the level of lipids in plasma.

Thyroid administration sufficient to increase markedly the basal metabolic rate had no obvious effect on the plasma lipids. Whatever therapeutic value thyroid may have in cases of nephrosis does not appear to depend on its effect on the level of lipids in plasma.

\section{BIBLIOGRAPHY}

1. Bright, R., Reports of Medical Cases Selected with a View of Illustrating the Symptoms and Cures of Diseases by Reference to Morbid Anatomy. Longman, Rus, Orme, Brown and Greene, London, 1827.

2. Christison, R., On Granular Degeneration of the Kidneys and its Connexion with Dropsy, Inflammations, and Other Diseases. Adam and Charles Black, Edinburgh, 1839.

3. Epstein, A. A., Concerning the causation of edema in chronic parenchymatous nephritis; methods for its alleviation. Am. J. M. Sc., 1917, 154, 638.

4. Page, I. H., Kirk, E., and Van Slyke, D. D., Plasma lipids in chronic hemorrhagic nephritis. J. Clin. Invest., 1936, 15, 101.

5. White, P., Diabetes in children. Bull. New York Acad. Med., 1934, 10, 347.

6. Dieballa, G., and Illyés, G. V., Stoffwechseluntersuchungen an Brightikern unter Schilddrüseneinwirkung. Arch. f. exper. Path. u. Pharmakol., 1897, $39,273$.

7. Percy, J. F., Thyroid extract in nephritis. A preliminary statement of a new and effective method of treatment. J. A. M. A., 1912, 59, 1708.

8. Percy, J. F., Nephritis. Its treatment with thyroid as a preliminary to operation. J. A. M. A., 1913, $61,380$.

9. Epstein, A. A., Further observations on the nature and treatment of chronic nephrosis. Am. J. M. Sc., 1922, 163, 167.

10. Liu, S. H., The effect of thyroid medication in nephrosis. Arch. Int. Med., 1927, 40, 73.

11. Epstein, A. A., and Lande, H., Studies on blood lipoids. I. The relation of cholesterol and protein deficiency to basal metabolism. Arch. Int. Med., 1922, 30, 563.

12. Luden, G., The blood cholesterol in malignant disease and the effect of radium on the blood cholesterol. Collected Papers of the Mayo Clinic, 1918, $10,470$.

13. Bing, H. J., and Heckscher, H., Der Fett-Cholesteringehalt des Blutes bei Patienten mit morbus Basedowii. Biochem. Ztschr., 1925, 158, 403.

14. Heckscher, H., Untersuchungen über den FettCholesterin-gehalt des Blutes bei thyreiodectomierten Pferden. Biochem. Ztschr., 1925, 158, 417.

15. Heckscher, H., Uber die Fett-Cholesterin-Menge des Blutes bei Kretinen. Biochem. Ztschr., 1925, 158, 422.

16. Nicholls, E. G., and Perlzweig, W. A., The plasma fats and the iodine absorption capacity of the fatty acids in hyperthyroidism. J. Clin. Invest., 1927-28, 5, 195.

17. Mason, R. L., Hunt, H. M., and Hurxthal, L., Blood cholesterol values in hyperthyroidism and hypothyroidism; their significance. New England J. Med., 1930, 203, 1273.

18. Knauer, H., Ergebnisse der Lipoidstoffwechselforschung. Verl. Karger, Berlin, 1928.

19. Wade, P. A., Clinical and experimental studies on calcium and cholesterol in relation to the thyroid parathyroid apparatus. Am. J. M. Sc., 1929, 177, 790.

20. Rémond, A., Colombiès, H., and Bernardbeig, J., Cholestérinémie thyro- et parathyroidienne. Le rôle de la parathyroïde dans le parallélisme de l'azotémie résiduelle et de la cholestérinémie. Compt. rend. Soc. de biol., 1924, 91, 445.

21. Parhon, C. I., and Dérévici, H., Note sur la glycémie le calcium et la cholestérine du sérum chez les animaux éthyroidés ou après ablation des para- 
thyroides et des thyroides. Compt. rend. Soc. de biol., 1926, 95, 787.

22. Westra, J. J., and Kunde, M. M., Blood cholesterol in experimental hypo- and hyperthyroidism (rabbit). Am. J. Physiol., 1933, 103, 1.

23. Gardner, J. A., and Gainsborough, H., The relationship of plasma cholesterol and basal metabolism. Brit. Med. J., 1928, 2, 935.

24. Hurxthal, L. M., Blood cholesterol in thyroid disease. I. Analysis of findings in toxic and in nontoxic goiter before treatment. Arch. Int. Med., 1933, 51, 22.

25. Hurxthal, L. M., Blood cholesterol in thyroid disease. II. Effect of treatment. Arch. Int. Med., 1933, 52, 86.

26. Kirk, E., Page, I. H., and Van Slyke, D. D., Gasometric microdetermination of lipids in plasma, blood cells, and tissues. J. Biol. Chem., 1934, 106, 203.

27. Mфller, E., McIntosh, J. F., and Van Slyke, D. D., Studies of urea excretion. IV. Relationship between urine volume and rate of urea excretion by patients with Bright's disease. J. Clin. Invest., 1928, 6, 485.
28. Van Slyke, D. D., Page, I. H., Hiller, Alma, and Kirk, Esben, Studies of urea excretion. IX. Comparison of urea clearances calculated from the excretion of urea, of urea plus ammonia, and of nitrogen determinable by hypobromite. J. Clin. Invest., 1935, 14, 901.

29. Addis, T., and Shevky, M. C., A test of the capacity of the kidney to produce a urine of high specific gravity. Arch. Int. Med., 1922, 30, 559.

30. Page, I. H., Kirk, E., Lewis, W. H., Jr., Thompson, W. R., and Van Slyke, D. D., Plasma lipids of normal men at different ages. J. Biol. Chem., 1935, 111, 613.

31. Moore, N. S., and Van Slyke, D. D., The relationships between plasma specific gravity, plasma protein content and edema in nephritis. J. Clin. Invest., 1930, 8, 337.

32. Page, I. H., and Heuer, G. J., The effect of renal denervation on patients suffering from nephritis. J. Clin. Invest., 1935, 14, 443.

33. Van Slyke, D. D., Page, I. H., Kirk, E., and Farr, L. E., Nature of nitrogenous constituents in petroleum ether extract of plasma. Proc. Soc. Exper. Biol. and Med., 1935, 32, 837. 